\title{
5-(Bis(3-(2-hydroxyethyl)- IH-indol-2-yl)methyl)- 2-hydroxybenzoic acid (BHIMHA): showing a strategy of designing drug to block lung metastasis of tumors
}

\author{
This article was published in the following Dove Press journal: \\ Drug Design, Development and Therapy \\ 16 February 2016 \\ Number of times this article has been viewed
}

\author{
Taiping Gan ${ }^{1,2}$ \\ Yuji Wang ${ }^{1,2}$ \\ Ming Zhao ${ }^{1-3}$ \\ Jianhui $\mathbf{W u}^{1,2}$ \\ Jian Yang ${ }^{4}$ \\ Shiqi Peng',2 \\ 'Beijing Area Major Laboratory \\ of Peptide and Small Molecular \\ Drugs, Engineering Research Center \\ of Endogenous Prophylactic of \\ Ministry of Education of China, \\ ${ }^{2}$ Beijing Laboratory of Biomedical \\ Materials, College of Pharmaceutical \\ Sciences, Capital Medical University, \\ Beijing, People's Republic of China; \\ ${ }^{3}$ Department of Biomedical Science \\ and Environmental Biology, Kaohsiung \\ Medical University, Kaohsiung, Taiwan; \\ ${ }^{4}$ Ludwig Center for Cancer Genetics \\ and Therapeutics Kimmel Cancer \\ Center, Johns Hopkins University \\ School of Medicine, USA
}

\begin{abstract}
Early metastasis is still the most recalcitrant factor in the treatment of lung cancer patients. By analyzing the structures and comparing the docking scores of the known pharmacophores, the authors of this paper designed 5-(bis(3-(2-hydroxyethyl)-1H-indol-2-yl)methyl)-2hydroxybenzoic acid (BHIMHA) as a promising lead compound to develop metastasis inhibitors. In vitro 5,10 , and $20 \mu \mathrm{M}$ of BHIMHA concentration dependently inhibited the migration and invasion of A549 cells. In vivo 0.4, 2.0, and $8.9 \mu \mathrm{mol} / \mathrm{kg}$ of BHIMHA dose dependently inhibited the metastasis of LLC (Lewis Lung Carcinoma) toward lung. In vivo, $2 \mu \mathrm{mol} / \mathrm{kg}$ of BHIMHA showed additional actions of slowing the growth of the primary tumor of C57BL/6 mice and S180 mice as well as inhibiting xylene-induced ear edema of the mice. Therefore, BHIMHA simultaneously blocked tumor metastasis toward lung, slowed the primary tumor growth, and limited the inflammation. These pharmacological actions were correlated with the inhibition of PKC $\alpha$ and NF- $\kappa \mathrm{B}$ expression.
\end{abstract}

Keywords: migration, invasion, lung metastasis, anticancer, anti-inflammation, $\mathrm{PKC} \alpha$ inhibitor

\section{Introduction}

Despite the advances in conventional and targeting therapies, lung cancer is one of the most aggressive human cancers. In the last decade, the early metastasis toward lung has been one of the most recalcitrant factors leading to failed treatment and high mortality rate of the cancer patients. ${ }^{1-4}$ Metastatic cascade of the cancer cells involves a series of events such as epithelial-mesenchymal transition, migration and invasion of cancer cells, the intravasation of the cancer cells toward the systemic circulation, the adhesion of the cancer cells onto endothelial cells, the extravasation of the cancer cells, the colonization of the cancer cells in distant organs, and the cancer cells-induced angiogenesis. ${ }^{5}$ Of the metastatic cascade, the migration and the invasion are the critical upstream events.

Protein kinase $\mathrm{C}$ (PKC) is a family of the kinases consisting of distinct isoforms of lipid-regulated serine/threonine kinases and exemplifies the specifically signaling molecules that link multiple cellular processes to cancer. The overexpression of PKC activated by phorbol esters promotes tumor development and is one of the biomarkers for cancer diagnosis. ${ }^{6,7}$ In respect of isoforms PKC $\alpha, \mathrm{PKC} \beta \mathrm{II}, \mathrm{PKC} \gamma, \mathrm{PKC} \eta, \mathrm{PKC} \delta$, and $\mathrm{PKC} \theta$, the regulation of $\mathrm{PKC} \alpha$ relates to the proliferation, survival, differentiation, and motility of the cancer cells. ${ }^{8}$ As a regulator, the expression of $\mathrm{PKC} \alpha$ is responsible for
Correspondence: Shiqi Peng; Ming Zhao Beijing Area Major Laboratory of Peptide and Small Molecular Drugs, Engineering Prophylactic of Ministry of Education of Materials, College of Pharmaceutical Sciences, Capital Medical University, No I0 Xitoutiao, You An Men, Beijing 100069, People's Republic of China Tel $+86 \quad 10839 \mid \quad 1528$ Fax +86 I0 839। 1535 Email sqpeng@bjmu.edu.cn; mingzhao@bjmu.edu.cn
Drug Design, Development and Therapy 2016:10 7|1-721

7 I I

Dovepress

http://dx.doi.org/10.2147/DDDT.S93570 (c) (7) (5) 2016 Gan et al. This work is published and licensed by Dove Medical Press Limited. The full terms of this license are available at https://www.dovepress.com/terms.php
and incorporate the Creative Commons Attribution - Non Commercial (unported, v3.0) License (http://creativecommons.org/licenses/by-nc/3.0/). By accessing the work you BY NC and incorporate the Creative Commons Attribution - Non Commercial (unported, v3.0) License (http://creativecommons.org/licenses/by-nc/3.0/). By accessing the work you
hereby accept the Terms. Non-commercial uses of the work are permitted without any further permission from Dove Medical Press Limited, provided the work is properly attributed. For permission for commercial use of this work, please see paragraphs 4.2 and 5 of our Terms (https://www.dovepress.com/terms.php). 
the invasion and metastasis of cancer cells..$^{9-12}$ For instance, in vitro the downregulation of $\mathrm{PKC} \alpha$ expression leads to the inhibition of the invasion and the migration of A549 cells, ${ }^{13,14}$ and in vivo not only is PKC $\alpha$ level is significantly higher in lung cancer tissue when compared to healthy lung tissue, but also the PKC $\alpha$ traffic in the nuclei is significantly increased when compared to the membrane. ${ }^{15,16}$ The knowledge means the downregulation of $\mathrm{PKC} \alpha$ expression would be essentially considered in designing the drug capable of blocking the metastasis of tumors toward the lung.

Inflammatory component contributes to the proliferation, angiogenesis, and metastasis of tumors. ${ }^{17}$ Nuclear factor- $\kappa \mathrm{B}$ $(\mathrm{NF}-\kappa \mathrm{B})$ not only correlates with the onset and the progression of cancer but also correlates with cancer-related inflammation, ie, NF- $\kappa \mathrm{B}$ leads to the cross-talk of inflammation with tumor growth, angiogenesis, and metastasis. ${ }^{18,19}$ The knowledge means the inhibition of NF- $\kappa \mathrm{B}$ expression also would be considered in designing the drug capable of blocking the metastasis of tumors toward the lung.

It is well known that staurosporine is an inhibitor of PKC and limits the invasive and metastatic abilities of lung tumor cells. ${ }^{20} \mathrm{BPIC}$ is an inhibitor of tumor growth and minimizes inflammatory response. ${ }^{21}$ MIAM upregulates sirtuin-3 and slows the growth of human hepatocellular carcinoma. ${ }^{22,23}$ Based on the pharmacophores from staurosporine, BPIC and MIAM, the drug could be capable of blocking the metastasis of tumors toward the lung. In this context, we surveyed the structural characteristics of staurosporine, BPIC, and MIAM; designed 5-(bis(3-(2- hydroxyethyl)-1H-indol-2-yl)methyl)2-hydroxyl benzoic acid (BHIMHA); assayed the in vitro activities of BHIMHA inhibiting the proliferation, migration, and invasion of the cancer cells; tested the in vitro effect of BHIMHA on the expression of PKCs and NF- $\mathrm{KB}$ from cancer cells; measured the in vivo efficacy of BHIMHA blocking the metastasis of the tumors toward the lung; evaluated the in vivo potency of BHIMHA slowing the tumor growth; and estimated the in vivo action of BHIMHA preventing the mice from xylene-induced ear edema.

\section{Materials and methods General}

The chemicals were purchased from Sigma-Aldrich Co. (St Louis, MO, USA) and were purified when necessary. Column chromatography was performed using silica gel (200-300 mesh, Qingdao Haiyang Chemical Co., Qingdao, People's Republic of China). Purity of BHIMHAM $(>95 \%)$ and BHIMHA $(>98 \%)$ were determined with TLC (thin-layer chromatography; Qingdao silica gel plates of GF254) and HPLC (CHIRALPAK AH-H column, 4.6×250 mm, Daicel Chemical Industries Ltd., Osaka, Japan), respectively.

${ }^{1} \mathrm{H}-\mathrm{NMR}$ (nuclear magnetic resonance) (800 MHz) and ${ }^{13} \mathrm{C}-\mathrm{NMR}(200 \mathrm{MHz})$ spectra were recorded on Bruker Avance II $800 \mathrm{MHz}$ spectrometer (Bruker Daltonik, Billerica, MA, USA) with DMSO- $d_{6}$ (dimethyl sulfoxide-d6) as the solvent and tetramethylsilane as internal standard. ESI/MS (electrospray ionization/mass spectroscopy) was tested on ZQ 2000 (Waters, Milford, MA, USA) and solariX FT-ICR mass spectrometer (Bruker Daltonik) consisting of an electrospray ionization/matrix-assisted laser desorption ionization dual ion source and 9.4 $\mathrm{T}$ superconductive magnet.

HaCaT-immortalized human epidermal cells (HaCaT cells), mice Lewis lung carcinoma cells (LLC cells), and human lung adenocarcinoma cell line A549 were purchased from ATCC, Manassas, VA, USA. Mice sarcoma S180 cells were purchased from the Animal Center of Peking University. Doxorubicin and bovine serum albumin (BSA) were purchased from Sigma. Roswell Park Memorial Institute1640 (RPMI 1640) medium, Dulbecco's Modified Eagle's Medium (DMEM), and fetal bovine serum (FBS) were purchased from Gibco; products of Thermo Fisher Scientific, Waltham, MA, USA. The inserts ( $8.0 \mu \mathrm{m}$ pores) of 24 -well transwell were purchased from Corning Incorporated (Corn-

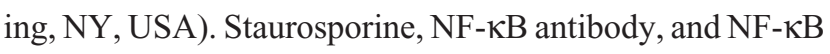
inhibitor ammonium pyrrolidinedithiocarbamate (PDTC) were purchased from Beyotime Institute of Biotechnology (Nantong, People's Republic of China). PKC $\alpha$, PKC $\beta I$, $\mathrm{PKC} \gamma, \mathrm{PKC} \eta$, and $\mathrm{PKC} \delta$ antibodies were purchased from Boster Biological Engineering Co., Ltd. (Wuhan, People's Republic of China); PKC $\theta$ antibody was purchased from CST (Shanghai) Biological Reagents Company Limited, Shanghai, People's Republic of China.

Male ICR mice and male C57BL/6 mice were purchased from the Animal Center of Peking University. The protocol was reviewed and approved by ethics committee of Capital Medical University. The committee assures that the welfare of the animals be maintained in accordance with the requirements of the Animal Welfare Act and in accordance with the NIH Guide for Care and Use of Laboratory Animals.

All experiments were performed at least in triplicate. Data are presented as mean \pm SD (standard deviation). The statistical analysis of all the biological data was carried out by use of analysis of variance (ANOVA) test. The $P$-value $<0.05$ was considered statistically significant.

\section{Design of BHIMHA}

As mentioned, the positive regulation of $\mathrm{PKC} \alpha$ relates to the proliferation, survival, differentiation, motility, invasion, 
and metastasis of the cancer cells. ${ }^{8-12}$ It was hypothesized that inhibiting PKC $\alpha$ expression would lead to the block of the metastasis of tumors toward the lung. The survey of structural characteristics of BPIC, MIAM, and staurosporine, the known PKC inhibitors, led to the design of BHIMHA as a novel inhibitor of PKC $\alpha$ (Figure 1). To theoretically ensure the rationality of the design, five members of PKC family, ie, PKC $\alpha$ (3iw4), PKC $\beta I I$ (3PFQ), PKC $\gamma$ (2E73),

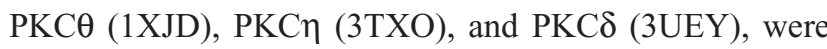
selected from Protein Data Bank (PDB) as the candidates of the target protein, and BHIMHA was docked into their active sites. The theoretical investigations demonstrated that of the five proteins, only the docking of BHIMHA toward the active site of $\mathrm{PKC} \alpha$ gave proper feature and higher docking score. In this case, the docking investigation of staurosporine toward the active site of PKC $\alpha$ was also performed, and the features and scores of BHIMHA and staurosporine are also shown in Figure 1.

\section{Synthetic route of BHIMHA}

As depicted in Figure 2, BHIMHA was prepared via a two-step procedure, ie, the Pictet-Spengler condensation of methyl-5-formyl-2-hydroxybenzoate and tryptophol, and the hydrolysis of 5-(bis(3-(2-hydroxyethyl)-1H-indol-2-yl)methyl)-2-hydroxy benzoate (BHIMHAM).

\section{Docking of BHIMHA into the active site of PKCs}

In the molecular docking, the structure of PKC $\alpha$ (3iw4), PKC $\beta I I$ (3PFQ), PKC $\gamma$ (2E73), PKC $\theta$ (1XJD), PKC $\eta$ (3TXO), and PKC $\delta$ (3UEY) from PDB was treated as rigid and prepared by AutoDockTools 1.5, ie, merging nonpolar

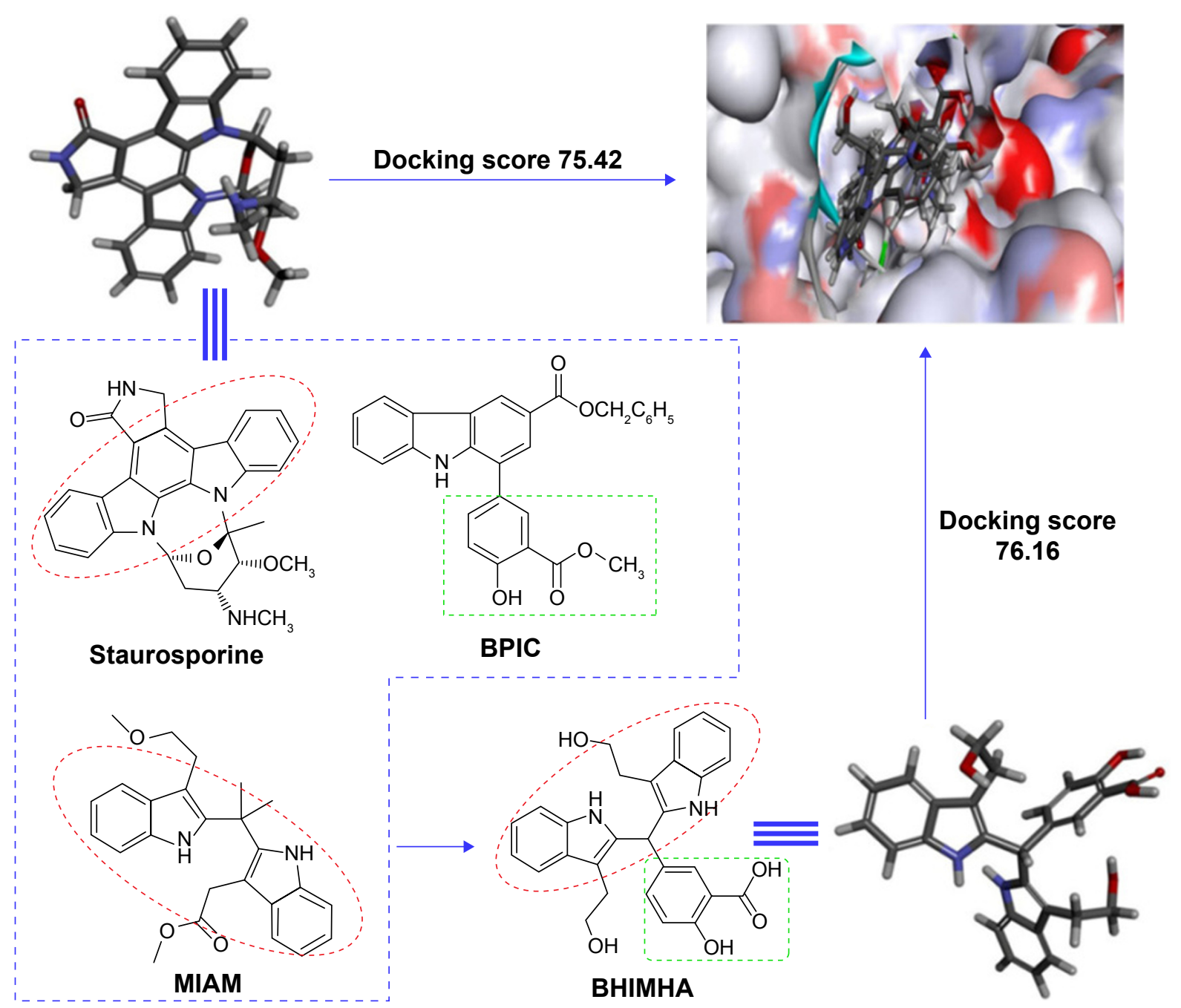

Figure I The survey of the structural characteristics of staurosporine, BPIC, and MIAM, as well as the docking scores results in BHIMHA as a novel inhibitor of PKC $\alpha$ (PDB: 3IW4) capable of inhibiting metastasis of tumor toward lung, slowing tumor growth, and blocking inflammatory response.

Abbreviations: Staurosporine, (5S,6R,7R,9R)-6-methoxy-5-methyl-7-methylamino-6,7,8,9, I5, 16-hexahydro-5H, I4H-17-oxa-4b,9a, I5-triaza-5,9-methanodibenzo[b, h]cyclonona [jk]-cyclopenta [e]-asindacen-I4-one; BPIC, benzyl I-[4-hydroxy-3-(methoxycarbonyl)phenyl-9H-pyrido[3,4-b]-indole-3-carboxylate; MIAM, \{2-[I-(3-methoxycarbonylmethyl-IHindol-2-yl)-I-methylethyl]-IHindol-3-yl\}acetic acid methyl ester; BHIMHA, 5-(bis(3-(2-hydroxyethyl)-IH-indol-2-yl)methyl)-2-hydroxybenzoic acid; PDB, Protein Data Bank. 


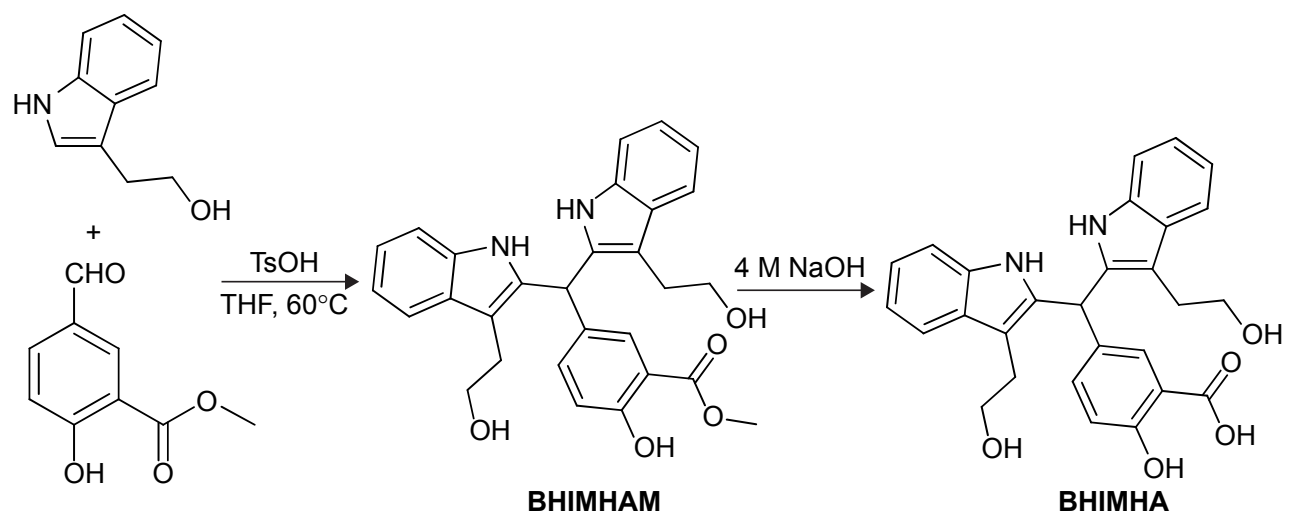

Figure 2 Synthesis route to BHIMHA.

Abbreviations: BHIMHAM, methyl 5-(bis(3-(2-hydroxyethyl)-IH-indol-2-yl)methyl)-2-hydroxybenzoate; BHIMHA, 5-(bis(3-(2-hydroxyethyl)-IH-indol-2-yl)methyl)-2hydroxybenzoic acid.

hydrogens and assigning gasteiger charges and autodock elements. Then, energy-minimized 3D conformations of staurosporine and BHIMHA were treated as flexible and prepared by AutoDockTools 1.5, ie, merging nonpolar hydrogens, assigning gasteiger charges, finding root and aromatic carbons, detecting rotatable bonds, and setting torsions. The grid box dimensions were set to $22.5 \AA \times 30 \AA \times 30 \AA$ using a grid spacing of $0.375 \AA$ for two average structures.

To determine the probable binding conformations, AutoDock4, a very popular docking program with a high success rate, and energy-minimized 3D conformations of staurosporine and BHIMHA were used to dock into the active site of PKC $\alpha$ (3iw4), PKC $\beta I I$ (3PFQ), PKC $\gamma$ (2E73),

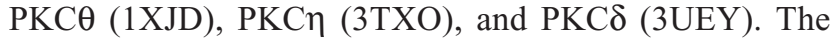
global optimization was started with parameters of a population of 100 randomly positioned individuals. The maximum number of energy evaluation was increased to $2.5 \times 10^{7}$, and the maximum number of generation in Lamarckian genetic algorithm was increased to $2.7 \times 10^{5}$. A Solis and Wets local search was performed with a maximum number of 3,000 . During each simulation, 256 runs were carried out for each agent. The resulting 256 conformations of staurosporine and BHIMHA were scored by the lowest binding energy and clustered using a root mean square tolerance of $2.0 \AA$. Lamarckian genetic algorithm was used to find the appropriate binding positions, orientations, and conformations of staurosporine and BHIMHA in the binding site.

\section{In vitro antiproliferation assay}

A549 cells, the carcinoma cells, were maintained in RPMI 1640 medium supplemented with $10 \%$ FBS, penicillin (100 U/mL), and streptomycin $(100 \mu \mathrm{g} / \mathrm{mL})$. HaCaT cells (control), the noncarcinoma cells, were maintained in DMEM medium supplemented with $10 \%$ FBS, penicillin (100 U/mL), and streptomycin $(100 \mu \mathrm{g} / \mathrm{mL})$. The cells were maintained in a humidified atmosphere of $5 \% \mathrm{CO}_{2}$ at $37^{\circ} \mathrm{C}$. The medium was renewed every 2 days. The proliferation of A549 cells and HaCaT cells was determined with MTT [3-(4,5-dimethylthiazol-2-yl)-2,5-diphenyltetrazolium bromide] assay. In brief, A549 cells or HaCaT cells in the logarithmic growth phase were digested with $0.25 \%$ trypsin, added to RPMI 1640 medium or DMEM medium supplemented with $10 \%$ FBS, plated into 96 -well plates $\left(5 \times 10^{3}\right.$ cells/well), and incubated for 6 hours. The cells were treated with BHIMHA (final concentration: 1, 10, 25, 50, and $100 \mu \mathrm{M}), 25 \mu \mathrm{L}$ solution of MTT in the medium $(5 \mathrm{mg} / \mathrm{mL})$ was added, and the plates were incubated at $37^{\circ} \mathrm{C}$ for 4 hours. The supernatant was discarded and to each well $100 \mu \mathrm{L}$ of DMSO was added. The optical density was read with Spectra Max M3 microplate reader (BioTek, Winooski, VT, USA) at $570 \mathrm{~nm}$. The optical density (OD) value of BHIMHA-treated well was compared with that of DMSO-treated well. The proliferation of A549 cells or HaCaT cells was represented with the OD value. Each measurement was performed in triplicate. Data are presented as mean \pm SD. The statistical analysis of all data was carried out by use of ANOVA test. The $P$-value $<0.05$ was considered statistically significant.

\section{A549 cell migration assay}

Transwell chamber with cell permeable membrane was used for migration assay of A549 cells as described previously. ${ }^{24}$ In brief, A549 cells $\left(5 \times 10^{4}\right.$ cells/chamber $)$ and serum-free medium in the upper chamber were treated with BHIMHA $(5,10$, and $20 \mu \mathrm{M})$. The medium with $10 \%$ FBS, the chemotactic factor, was added into the down chamber (600 $\mu \mathrm{L} /$ chamber), the transwell chamber was incubated at $37^{\circ} \mathrm{C}$ for 6 hours, and the cells that did not penetrate the membrane and at the bottom of the upper chamber were removed with cotton swabs. The cells were fixed with phosphate-buffered saline (PBS) containing 4\% 
formaldehyde for 30 minutes and stained with $0.1 \%$ crystal violet for 15 minutes. The cells that penetrated through the membrane into the down chamber were counted under a light microscope at $\times 200$ to take the count of the cells from six visual fields.

\section{A549 cell invasion assay}

Transwell chambers were used for A549 cell invasion assay as described previously. ${ }^{24}$ Membrane at the bottom of each chamber was coated with $50 \mu \mathrm{L}$ matrigel and airdried overnight. The chamber was blocked with BSA $(2 \%$, $50 \mu \mathrm{L} /$ chamber), incubated at $37^{\circ} \mathrm{C}$ for 2 hours, and rinsed with PBS. A549 cells $\left(2 \times 10^{4}\right.$ cells/chamber $)$ and serum-free medium in the upper chamber were treated with BHIMHA $(5,10$, and $20 \mu \mathrm{M})$. Into the down chamber, $600 \mu \mathrm{L}$ of FBS $\left(10 \%\right.$, control) was added. A549 cells were cultured at $37^{\circ} \mathrm{C}$ for 24 hours and the cells that did not penetrate the membrane were removed with cotton swabs. The cells penetrated through the membrane were fixed with $4 \%$ formaldehyde for 30 minutes and stained with $0.1 \%$ crystal violet for 10 minutes. The cells that penetrated through the matrigel were counted under a light microscope at $\times 200$ to take the count of the cells from six visual fields. Data are presented as mean $\pm \mathrm{SD}$. The statistical analysis of the data was carried out by use of ANOVA test. The $P$-value $<0.05$ was considered statistically significant.

\section{Western blot assay}

A549 cells $\left(2 \times 10^{6} /\right.$ well $)$ were seeded in 6-well plates overnight and treated with $5 \mu \mathrm{M}$ of BHIMHA, $0.1 \mu \mathrm{M}$ of staurosporine, and $1 \mu \mathrm{M}$ of PDTC for 24 hours. The cells were harvested, washed twice with PBS, and at $4^{\circ} \mathrm{C}$, lysed with ice-cold radioimmunoprecipitation assay buffer $(1 \%$ $\mathrm{NP}-40$ in $150 \mathrm{mM} \mathrm{NaCl}, 50 \mathrm{mM}$ Tris, and $2 \mathrm{mM}$ EDTA) for 30 minutes. The protein from the lysate was run on a sodium dodecyl sulfate-polyacrylamide gel, and the bands were transferred to polyvinylidene difluoride membrane. The membrane was blocked with 5\% (w/v) BSA for 2 hours, washed thrice with Tris Buffered Saline Tween (TBST), and at $4{ }^{\circ} \mathrm{C}$ incubated with primary antibodies PKC $\alpha$ or PKC $\beta I$ or $\mathrm{PKC} \gamma$ or PKC $\eta$ or PKC $\delta$ or NF- $\mathrm{KB}$ (p65, 1:1,000) overnight. The membrane was washed and incubated for 1 hour (at room temperature) with IgG-horseradish peroxidase conjugated secondary antibody and washed thrice with TBST. Western blot chemiluminescence reagents were added for visualizing the bands of the proteins. The data are presented as mean $\pm \mathrm{SD}$. The statistical analysis of the data was carried out by use of ANOVA test. The $P$-value $<0.05$ was considered statistically significant.

\section{Tumor metastasis assay}

Tumor metastasis was studied with LLC model as described previously. ${ }^{25}$ In brief, subcutaneous tumors were implanted by injecting $1.5 \times 10^{7}$ viable LLC cells in $0.2 \mathrm{~mL}$ of normal saline (NS) into the skin of the right armpit of 8-week-old C57BL/6 mice. Nine days after LLC cell injection, the tumor reached $\sim 50 \mathrm{~mm}^{3}$ and the treatment was initiated. The mice were randomly divided to NS-treated group (oral dose: $10 \mathrm{~mL} / \mathrm{kg} / \mathrm{d}, 12$ consecutive days) and BHIMHA-treated groups (oral dose: 8.9, 2.0, and $0.4 \mu \mathrm{mol} / \mathrm{kg} / \mathrm{d}, 12$ consecutive days). In mice, tumor weight and volume were recorded on 13th day and used to represent the activity. Twenty four hours after the last dosage, all mice were weighed, received ether anesthesia, killed, and immediately dissected to obtain the tumor samples for tests. Data are presented as mean \pm SD (standard deviation). The statistical analysis of the data was carried out by use of ANOVA test. The $P$-value $<0.05$ was considered statistically significant.

\section{In vivo antitumor assay}

Male ICR mice were 10 weeks old at the beginning of in vivo antitumor assay. ${ }^{26} \mathrm{~S} 180$ cells were subcutaneously injected to form solid tumors. The cells obtained in ascitic form from tumor-bearing mice were serially transplanted once per week. The subcutaneous tumors were implanted under mouse skin at the right armpit by injecting $0.2 \mathrm{~mL}$ of NS containing $2 \times 10^{6}$ viable tumor cells. Twenty four hours after implantation, the mice were randomly divided to BHIMHA (oral dose: $0.4,2.0$ and $8.9 \mu \mathrm{mol} / \mathrm{kg} / \mathrm{d}, 12$ consecutive days) treatment groups (36 mice), doxorubicin (Dox, intraperitoneal dose: $2 \mu \mathrm{mol} / \mathrm{kg} / \mathrm{d}, 12$ consecutive days, $12 \mathrm{mice}$ ), or NS (oral dose: $10 \mathrm{~mL} / \mathrm{kg} / \mathrm{d}, 12$ consecutive days, 12 mice). Mice were weighed daily. Twenty four hours after the last dosage, the mice were weighed and killed with ether anesthesia to obtain the organs and the tumor immediately. Data are presented as mean \pm SD. The statistical analysis of the data was carried out by use of ANOVA test. The $P$-value $<0.05$ was considered statistically significant.

\section{In vivo xylene-induced ear edema assay}

Male ICR mice were 10 weeks old at the beginning of in vivo xylene-induced ear edema assay. ${ }^{21}$ The mice were randomly divided into BHIMHA-treated (oral dose: 0.4, 2.0 and $8.9 \mu \mathrm{mol} / \mathrm{kg}, 30 \mathrm{mice}$ ) groups, aspirin-treated (oral dose: 0.11 and $1.11 \mathrm{mmol} / \mathrm{kg}, 20$ mice) groups, and NS orally treated group (10 mice). Thirty minutes after administration, $0.03 \mathrm{~mL}$ of xylene was applied to both anterior and posterior surfaces of the right ear of the mice. The left ear was used as a control. Two hours after xylene application, 
the mice were anesthetized with ether and killed for removal of both ears. The circular punches were taken with bores of $7 \mathrm{~mm}$ in diameter and weighed. The increase in weight caused by xylene irritant was calculated by subtracting the weight of the untreated left ear punch from the weight of the treated right ear punch. Data are presented as mean \pm SD. The statistical analysis of the data was carried out by use of ANOVA test. The $P$-value $<0.05$ was considered statistically significant.

\section{Results and discussion \\ The yield and chemical physical data of BHIMHAM}

At $60^{\circ} \mathrm{C}$, the 10 -hour Pictet-Spengler condensation of a mixture of $1.66 \mathrm{~g}(10 \mathrm{mmol})$ of methyl-5-formyl-2-hydroxybenzoate, $3.22 \mathrm{~g}(20 \mathrm{mmol})$ of tryptophol and $0.17 \mathrm{~g}(1 \mathrm{mmol})$ of TsOH provided $3.8 \mathrm{~g}(78 \%)$ of BHIMHAM as light yellow powders. FT-MS (m/e) 485.20627 [M + H] (calculated 485.19982). ${ }^{1} \mathrm{H}-\mathrm{NMR}\left(800 \mathrm{MHz}, \mathrm{DMSO}-d_{6}\right) \delta=10.52(\mathrm{~s}, 2 \mathrm{H}), 10.47$ (s, $\left.1 \mathrm{H}\right)$, $7.58(\mathrm{~s}, 1 \mathrm{H}), 7.50$ (d, $J=8 \mathrm{~Hz}, 2 \mathrm{H}), 7.30$ (d, $J=8 \mathrm{~Hz}, 2 \mathrm{H}), 7.25$ (d, $J=8.8 \mathrm{~Hz}, 2 \mathrm{H}), 7.04$ (t, $J=7.2 \mathrm{~Hz}, 2 \mathrm{H}), 6.97$ (t, $J=7.2 \mathrm{~Hz}, 2 \mathrm{H})$, $6.95(\mathrm{~d}, J=8.8 \mathrm{~Hz}, 1 \mathrm{H}), 6.08(\mathrm{~s}, 1 \mathrm{H}), 3.80$ (s, 3H), 3.53 (m, 2H), 3.49 (m, 2H), $2.86(\mathrm{~m}, 4 \mathrm{H}) .{ }^{13} \mathrm{C}-\mathrm{NMR}(200 \mathrm{MHz}$, DMSO- $\left.d_{6}\right) \delta / \mathrm{ppm}=169.67,160.34,138.79,136.21,135.97$, $135.45,129.49,123.85,121.19,118.89,118.69,117.98$, $113.25,109.31,61.94,56.50,55.38,52.90,45.56,39.79$, $39.69,31.15,28.35,19.03$.

\section{The yield and chemical physical data of BHIMHA}

At $0^{\circ} \mathrm{C}$, the 24-hour hydrolysis of BHIMHAM in $20 \mathrm{~mL}$ of solution of methanol and aqueous $\mathrm{NaOH}(\mathrm{pH} 12,4 \mathrm{M})$ provided $1.08 \mathrm{~g}$ (93\%) of BHIMHA as light gray powders.
FT-MS (m/e) $469.17775[\mathrm{M}-\mathrm{H}]^{-}$(calculated 469.18417). ${ }^{1} \mathrm{H}-\mathrm{NMR}\left(800 \mathrm{MHz}, \mathrm{DMSO}-d_{6}\right) \delta=10.53$ (s, 2H), 7.53 (s, 1H), 7.50 (d, $J=8 \mathrm{~Hz}, 2 \mathrm{H}), 7.30$ (d, $J=8 \mathrm{~Hz}, 2 \mathrm{H}), 7.26$ (d, $J=8.8 \mathrm{~Hz}, 2 \mathrm{H}), 7.03(\mathrm{t}, J=7.2 \mathrm{~Hz}, 2 \mathrm{H}), 6.97$ (t, $J=7.2 \mathrm{~Hz}, 2 \mathrm{H})$, $6.92(\mathrm{~d}, J=8.8 \mathrm{~Hz}, 1 \mathrm{H}), 6.07$ (s, 1H), $3.53(\mathrm{~m}, 2 \mathrm{H}), 3.49(\mathrm{~m}$, 2H), $2.85(\mathrm{t}, J=7.2 \mathrm{~Hz}, 4 \mathrm{H}) .{ }^{13} \mathrm{C}-\mathrm{NMR}\left(200 \mathrm{MHz}, \mathrm{DMSO}-d_{6}\right)$ $\delta / \mathrm{ppm}=170.80,160.35,136.19,136.02,1325.48,132.76$, $129.78,128.52,121.18,118.88,118.67,117.63,113.03$, $111.59,109.31,61.97,60.22,28.37,21.52,21.23,14.56$. These data demonstrate that via Pictet-Spengler condensation and hydrolysis, BHIMHA is successfully prepared in $73 \%$ yield and no rigorous conditions are required, which should benefit its preparation in large scale.

\section{BHIMHA fits the active site of PKC $\alpha$}

It is well documented that the interactions of a peptide ligand with the active site of $\mathrm{PKC} \alpha$ involve a number of amino acid residues such as Val420, Asp467, Leu345, Phe350, and Val353. ${ }^{27}$ Accordingly, the interactions were disclosed with docking investigation and are shown in Figure 3. The hydrogen, Van der Waals, and hydrophobic interactions between BHIMHA and the residues Val420, Asp467, Leu345, Phe350, and Val353 of the active site are amplified and these are clearly shown in Figure 3A. The data mean that in the active site of PKC $\alpha$ the peptide ligand and BHIMHA have the same action. Similarly, the hydrogen, Van der Waals, and hydrophobic interactions between staurosporine and the residues Val420, Asp467, Leu345, Phe350, and Val353 of the active site are amplified and these are clearly shown in Figure 3B. The data also mean that in the active site of PKC $\alpha$, the peptide ligand and staurosporine have the same action. Therefore, the docking investigations suggest that BHIMHA is worthy of the experimental assays.
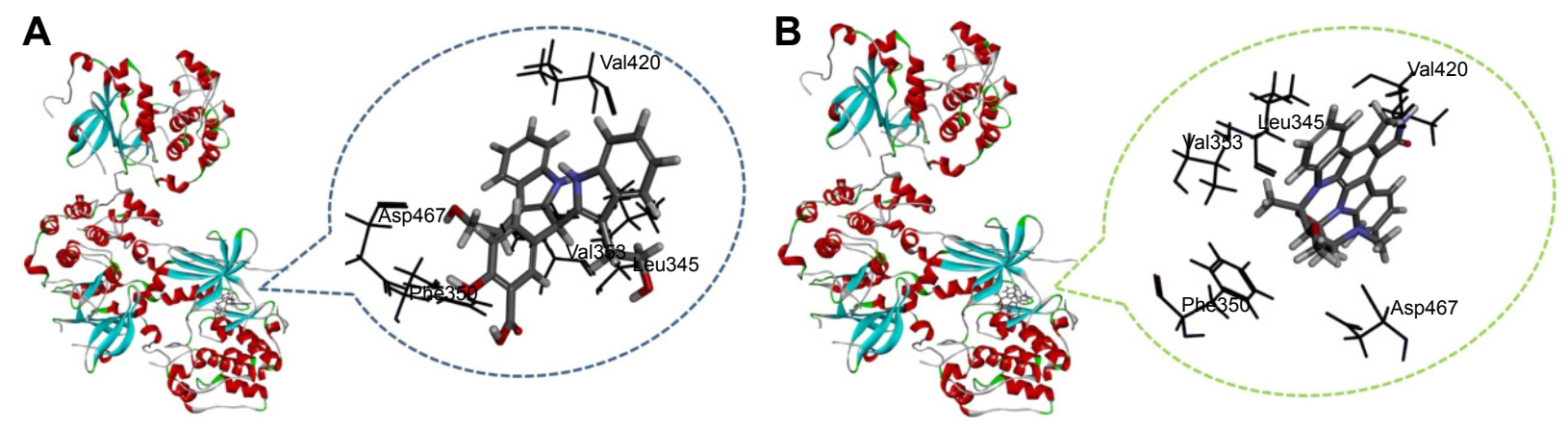

Figure 3 Docking investigation of BHIMHA and staurosporine toward PKC $\alpha$ (PDB: 3IW4).

Notes: (A) The feature of BHIMHA in the active site of $\mathrm{PKC} \alpha$, and the amplified interactions of energy minimized BHIMHA with the amino acid residues. (B) The feature of staurosporine in the active site of $\mathrm{PKC} \alpha$, and the amplified interactions of energy minimized staurosporine with the amino acid residues.

Abbreviations: PKC, protein kinase C; BHIMHA, 5-(bis(3-(2-hydroxyethyl)-IH-indol-2-yl)-methyl)-2-hydroxybenzoic acid; staurosporine, (5S,6R,7R,9R)-6-methoxy-5-methyl7-methyl-amino-6,7,8,9, I5, I6-hexahydro-5H, I4H-17-oxa-4b,9a, I5-triaza-5,9-methanodibenzo[b, h]cyclone-na[jk]cyclopenta[e]asindacen-14-one; PDB, Protein Data Bank. 


\section{BHIMHA did not affect the proliferation of $\mathrm{A} 549$ cells and $\mathrm{HaCaT}$ cells}

The effect of BHIMHA $(1,10,25,50$, and $100 \mu \mathrm{M})$ on the proliferation of A549 cells was examined with MTT assay. It was found that in the presence of $20 \mu \mathrm{M}$ BHIMHA, the 48-hour incubation gave A549 cells $88.33 \% \pm 0.98 \%$ of survival, and in the presence of $100 \mu \mathrm{M}$ BHIMHA the 48-hour incubation gave A549 cells $58.44 \% \pm 3.58 \%$ of survival. Therefore, 5,10 , and $20 \mu \mathrm{M}$ of BHIMHA were used for in vitro experiments. The effect of BHIMHA $(1,10,25,50$, and $100 \mu \mathrm{M})$ on the proliferation of $\mathrm{HaCaT}$ cells was examined with MTT assay. It was found that in the presence of 1, 10, 25, 50, and $100 \mu \mathrm{M}$ BHIMHA the 48-hour incubations gave HaCaT cells $93.51 \% \pm 6.35 \%, 90.24 \% \pm 7.65 \%, 89.23 \% \pm 7.35 \%$, $86.55 \% \pm 6.78 \%$, and $80.6 \% \pm 7.42 \%$ of survivals, respectively, demonstrating that the $\mathrm{IC}_{50}$ value of BHIMHA against $\mathrm{HaCaT}$ cell proliferation is higher than $100 \mu \mathrm{M}$ and has no cytotoxic action on noncarcinoma cells.

\section{BHIMHA inhibited A549 cell migration}

To show the effect of BHIMHA on the migration, the transwell migration assay of A549 cells was performed. The stained feature and the counted number of the migrated cells are represented with purple particles and are shown in Figure 4A and C. Figure 4A visualizes that 6 hours after the incubation 5,10 , and $20 \mu \mathrm{M}$ of BHIMHA concentration dependently inhibits the migration of A549 cells. Figure 4C indicates that the migrating number of A549 cells treated with 5,10 , and $20 \mu \mathrm{M}$ of BHIMHA gradually decreases.

\section{BHIMHA inhibited A549 cell invasion}

To show the effect of BHIMHA on the invasion, the transwell invasion assay of A549 cells was performed. The stained feature and the counted number of the invasion cells are represented with purple particles and are shown in Figure 4B and D. Figure 4B visualizes that 24 hours after incubation 5,10 , and $20 \mu \mathrm{M}$ of BHIMHA concentration dependently
A
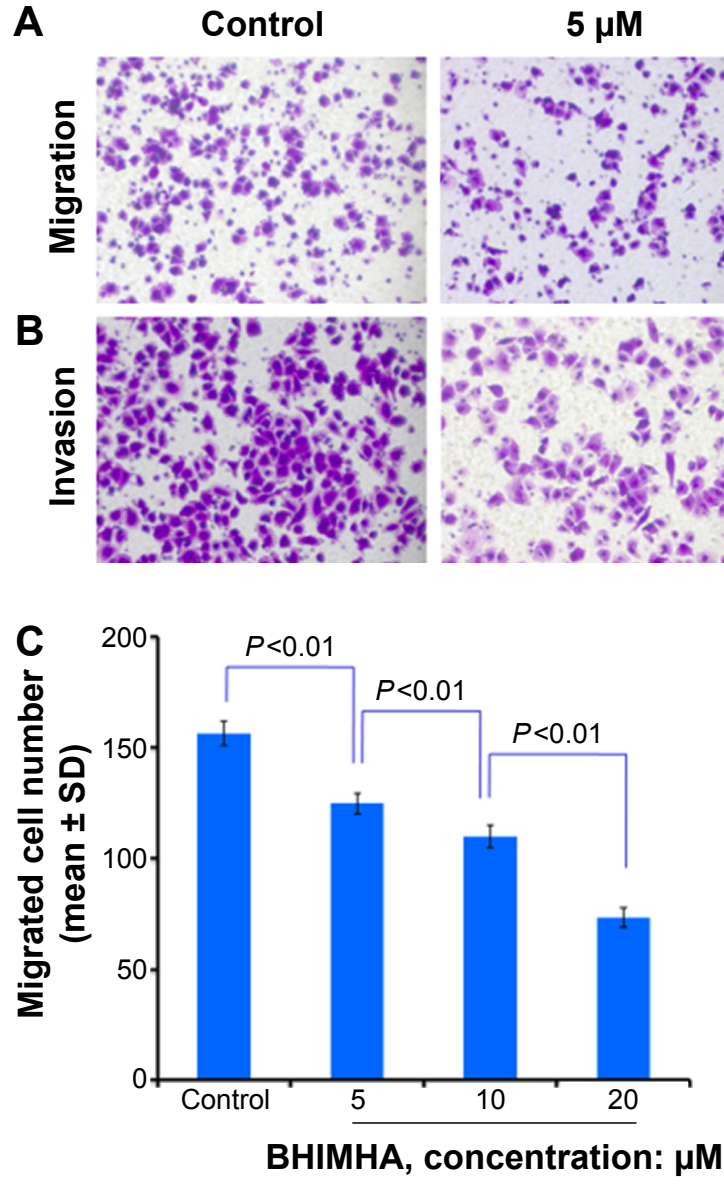

$5 \mu \mathrm{M}$
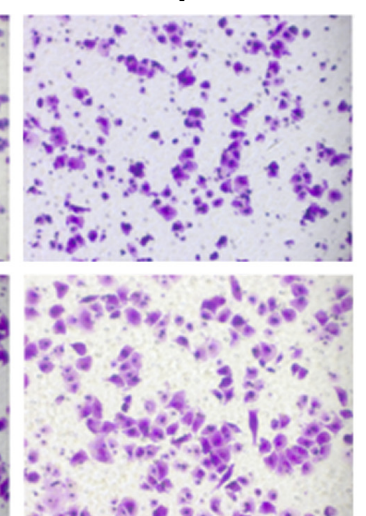

$10 \mu \mathrm{M}$
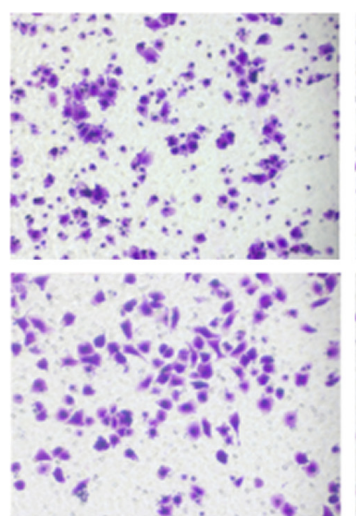
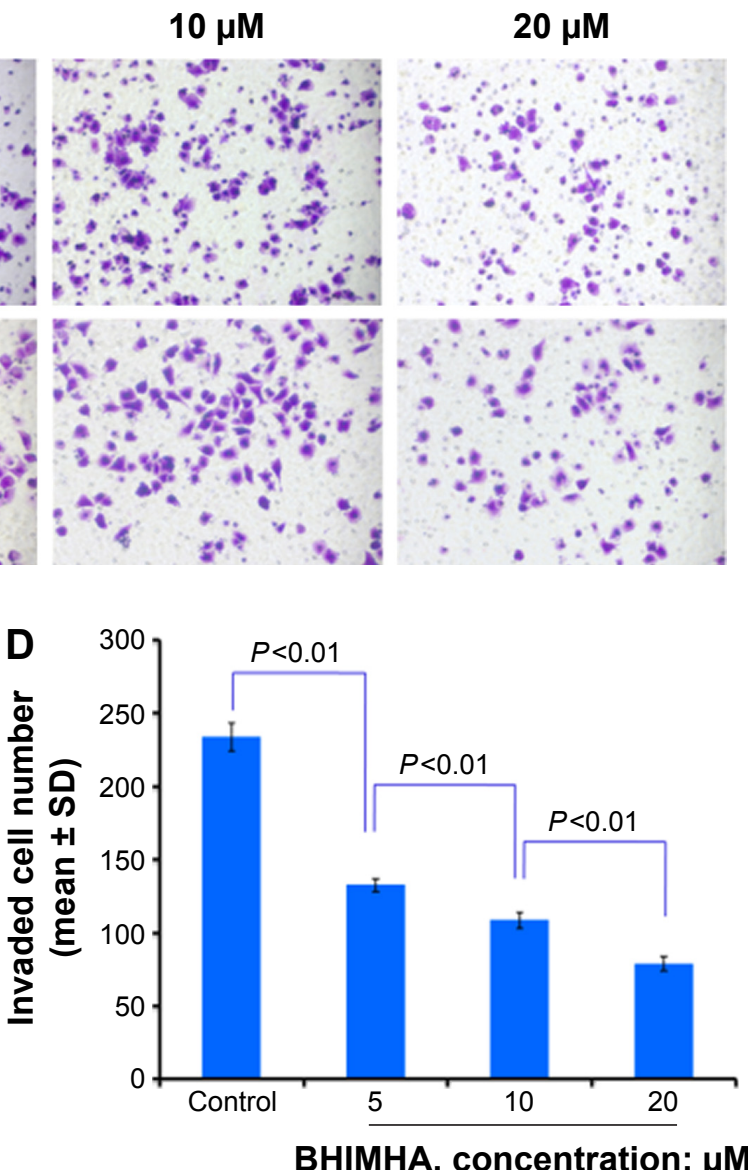

Figure 4 Effect of BHIMHA on migration and invasion of A549 cells (purple particles).

Notes: (A) Migration A549 cells in transwell chambers treated with BHIMHA for 6 hours; (B) invasion A549 cells in matrigel-coated transwell chambers treated with BHIMHA for 24 hours; (C) concentration dependence of BHIMHA inhibiting migration of A549 cells; and (D) concentration dependence of BHIMHA inhibiting invasion of A549 cells; $n=3$.

Abbreviations: SD, standard deviation; BHIMHA, 5-(bis(3-(2-hydroxyethyl)-IH-indol-2-yl)-methyl)-2-hydroxybenzoic acid. 
inhibits the invasion of A549 cells. Figure 4D indicates that the invasion number of A549 cells treated with 5, 10, and $20 \mu \mathrm{M}$ of BHIMHA gradually decreases.

\section{BHIMHA inhibited the metastasis of LLC cells from planted tumor toward the lung of C57BL/ 6 mice}

The effect of 12 days' treatment of BHIMHA on the metastasis of the planted LLC cells toward the lungs of C57BL/6 mice is represented with the number of metastatic tumor nodules. Figure $5 \mathrm{~A}$ shows the dose $(0.4,2.0$, and $8.9 \mu \mathrm{mol} / \mathrm{kg} / \mathrm{d})-$ dependent effect of BHIMHA on the number of the metastatic lung tumor nodule (labeled with blue ring). Figure 5B shows the number of the metastatic tumor nodules in the lungs of the mice orally receiving BHIMHA, and suggests that the inhibition is also a dose-dependent action.

\section{Effect of BHIMHA on PKC $\alpha$ expression from A549 cells}

As mentioned earlier that, the regulation of $\mathrm{PKC} \alpha$ relates to the proliferation, survival, differentiation, and motility of the cancer cells, ${ }^{8}$ and positively regulates the invasion and the metastasis. ${ }^{9-12}$ For instance, the inhibition of PKC $\alpha$ expression leads to the inhibition of the invasion and migration of A549 cells. ${ }^{13,14}$ To clarify the reproducibility of the design, the action mode of BHIMHA inhibiting the migration, invasion, and metastasis of the cancer cells was explained with the expression of PKC $\alpha$ or PKC $\beta$ II or PKC $\gamma$ or PKC $\eta$ or PKC $\delta$ or PKC $\theta$ from A549 cells by performing Western blot assay. Of the six antibodies, only PKC $\alpha$ gave useful result. Figure $5 \mathrm{C}$ and $\mathrm{D}$ show that 24 hours after the incubation, $5 \mu \mathrm{M}$ of BHIMHA effectively decreases the intensity of $\mathrm{PKC} \alpha$ band, correlating the downregulation of $\mathrm{PKC} \alpha$ expression with the inhibition of the migration and invasion of A549 cells, and additionally with the metastasis of LLC tumor toward the lung. However, the downregulation of $\mathrm{PKC} \alpha$ expression may result from quite different cellular mechanism. How BHIMHA inhibits PKC $\alpha$ expression and whether this inhibition is a result of directly affecting PKC $\alpha$ itself or a result of indirectly affecting the upstream kinases of $\mathrm{PKC} \alpha$ remains to be known.

\section{Effect of BHIMHA on LCC tumor growth of C57BL/6 mice}

To clarify the effect of 12-day treatment of BHIMHA on the growth of the primary tumor of C57BL/6 mice planted with LLC cells, the tumor weights were measured. Figure 6 shows the weights of the primary tumors of the C57BL/6 mice receiving NS and BHIMHA $(0.4,2.0$, and $8.9 \mu \mathrm{mol} / \mathrm{kg} / \mathrm{d})$, and suggests BHIMHA dose dependently slows the growth
A

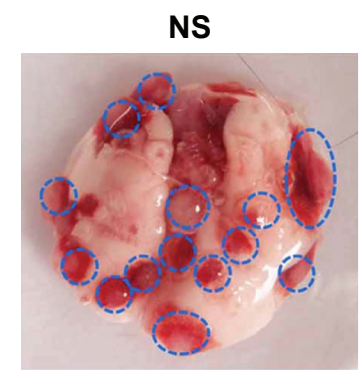

B

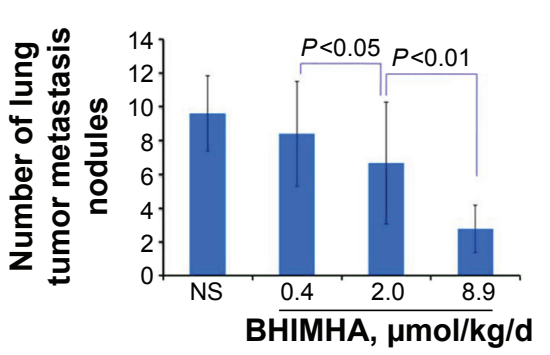

$0.4 \mu \mathrm{mol} / \mathrm{kg}$

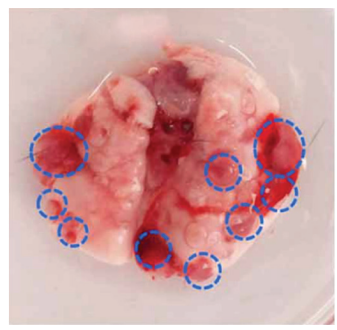

C

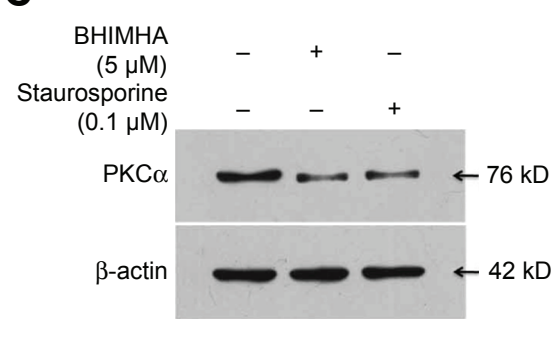

$2.0 \mu \mathrm{mol} / \mathrm{kg}$

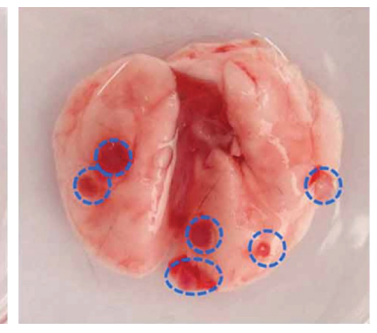

D

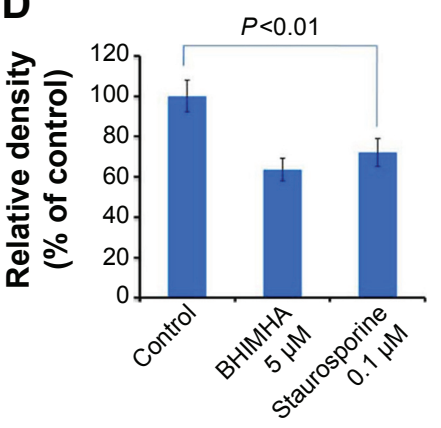

Figure 5 In vivo BHIMHA dose dependently inhibits the metastasis of tumor toward lung.

Notes: (A) Representative photographs of LLC tumor metastasis lungs of the mice treated with NS and BHIMHA. (B) On LLC metastasis model BHIMHA inhibited metastasis of C57BL/6 mice, $n=10$. (C, D) Western blot assay showing the effect of BHIMHA on the expression of PKC $\alpha$ from A549 cells, $n=3$.

Abbreviations: NS, normal saline; LLC, Lewis lung carcinoma; PKC $\alpha$, protein kinase C $\alpha$; BHIMHA, 5-(bis-(3-(2-hydroxyethyl)-IH-indol-2-yl)methyl)-2-hydroxybenzoic acid; staurosporine, (5S,6R,7R,9R)-6-methoxy-5-methyl-7-methylamino-6,7,8,9, I5, I6-hexahydro-5H, I4H-I7-oxa-4b,9a, I 5-triaza-5,9-methano-dibenzo[b, h]cyclonona[jk] cyclopenta[e]asindacen-I4-one. 


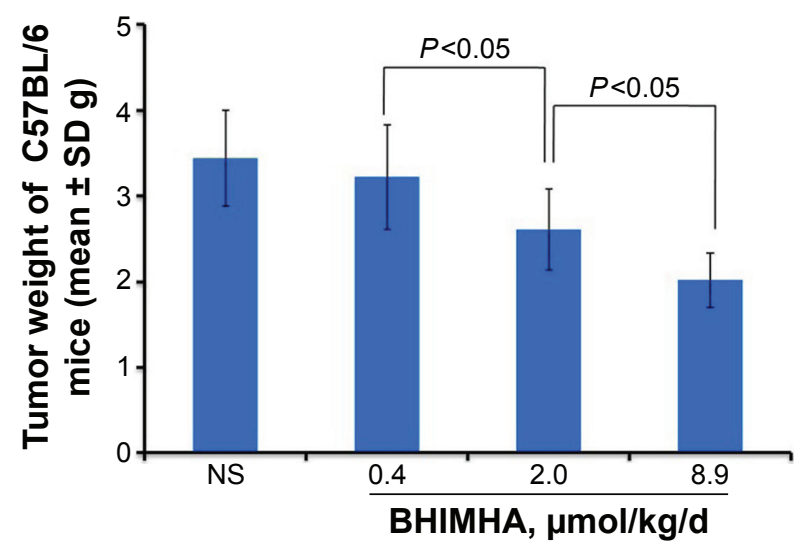

Figure 6 In vivo oral BHIMHA dose dependently inhibits the growth of the primary tumor of LLC planted C57BL/6 mice $(n=10)$.

Abbreviations: NS, normal saline; LLC, Lewis lung carcinoma; SD, standard deviation; BHIMHA, 5-(bis(3-(2-hydroxyethyl)-IH-indol-2-yl)methyl)-2-hydroxybenzoic acid.

of LLC planted C57BL/6 mice and its minimal effective dose is $2 \mu \mathrm{mol} / \mathrm{kg} / \mathrm{d}$.

\section{Effect of BHIMHA on tumor growth of SI 80 mice}

The in vivo inhibition of 12-day treatment of BHIMHA to the primary tumor was further examined on S180 mouse model. Figure 7 shows the tumor weights of S180 mice treated with NS $(10 \mathrm{~mL} / \mathrm{kg} / \mathrm{d})$ and BHIMHA $(0.4,2.0$ and $8.9 \mu \mathrm{mol} / \mathrm{kg} / \mathrm{d})$, ensures BHIMHA dose dependently slows the tumor growth of $\mathrm{S} 180$ mice and shows a minimal effective dose of $2 \mu \mathrm{mol} / \mathrm{kg} / \mathrm{d}$. Thus, either for LLC planted C57BL $/ 6$ mice or for $\mathrm{S} 180$ cells planted ICR mice $2 \mu \mathrm{mol} / \mathrm{kg} / \mathrm{d}$ of oral BHIMHA effectively slows the tumor growth, and emphasizes that in addition to inhibiting the metastasis of tumor toward lung BHIMHA is capable of inhibiting the primary tumor to grow.

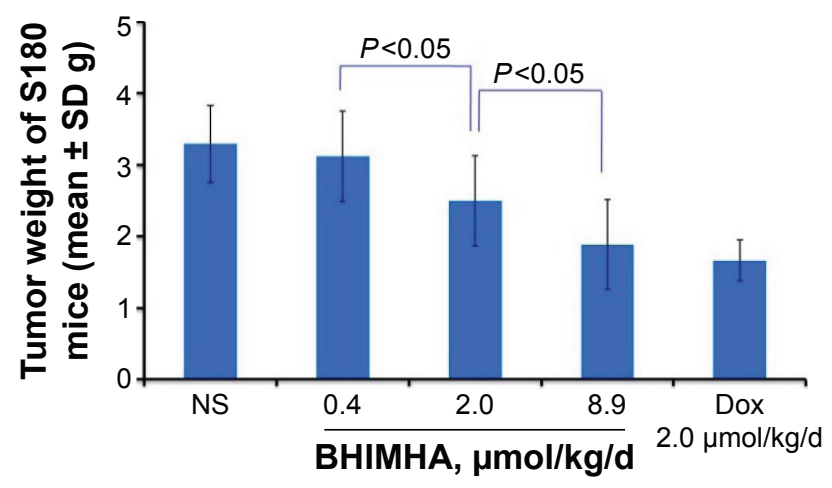

Figure 7 In vivo activities of BHIMHA, Dox and NS in slowing tumor growth of $\mathrm{S} 180$ mice, $\mathrm{n}=12$.

Abbreviations: NS, normal saline; Dox, doxorubicin; SD, standard deviation; BHIMHA, 5-(bis(3-(2-hydroxyethyl)-IH-indol-2-yl)methyl)-2-hydroxybenzoic acid.
It is well known that the regulation of PKC could be a double-edged sword-like event. On one hand, tumorinhibiting effects of PKC inhibitors have long been aimed at the discovery of potential antitumor agents, but result in disappointing outcomes. On the other hand, the inhibition of PKC activity or the downregulation of the expression of PKC protein usually causes cancer onset. This means that inhibition of PKC may not be a feasible strategy of tumor therapy. Thus, the efficacy of BHIMHA in slowing tumor growth in vivo should be considered a supplementary benefit to the inhibition of the metastasis of the tumor toward lung.

\section{Effect of BHIMHA on ICR mice developing inflammation}

The anti-inflammation activities of BHIMHA $(0.4,2.0$, or $8.9 \mu \mathrm{mol} / \mathrm{kg}$ ) were evaluated on xylene-induced ear edema. Figure 8A shows that oral BHIMHA dose dependently reduces xylene-induced ear edema of the mice and has a minimal effective dose of $2 \mu \mathrm{mol} / \mathrm{kg}$. Besides, the potency of reducing ear edema of $8.9 \mu \mathrm{mol} / \mathrm{kg}$ of BHIMHA equals that of $0.11 \mathrm{mmol} / \mathrm{kg}$ of aspirin $(P>0.05)$, which means the anti-inflammation activity of BHIMHA is 12-fold higher than that of aspirin. In addition to inhibiting the metastasis of the tumor toward lung and inhibiting the growth of the primary tumors, BHIMHA also effectively inhibits the inflammatory response.

\section{Effect of BHIMHA on NF- $\kappa B$ expression of A549 cells}

Inflammation is a process of innate immunity in response to physical, physiological, and/or oxidative stress and correlates with the activation of NF- $\kappa \mathrm{B}$ signaling pathway. To correlate the inhibition of inflammation with the downregulation of the expression of NF- $\kappa$ B from BHIMHA-treated A549 cells, the Western blot assay was performed, and PDTC was used as a positive control. Figure $8 \mathrm{~B}$ and $\mathrm{C}$ show that 24 hours after incubation, $5 \mu \mathrm{M}$ BHIMHA effectively decreases the intensity of NF- $\kappa \mathrm{B}$ band. Thus, it would be proposed that by blocking NF- $\kappa \mathrm{B}$ signaling pathway BHIMHA inhibits the mice to develop xylene-induced inflammation.

\section{Conclusion}

The survey of the structural characteristic of staurosporine, BPIC, and MIAM, as well as the docking toward the active sites of PKCs led to a rational design of BHIMHA capable of inhibiting the metastasis of tumor toward lung, slowing the tumor growth, and blocking inflammatory response. In vitro, BHIMHA concentration dependently inhibits the 
A

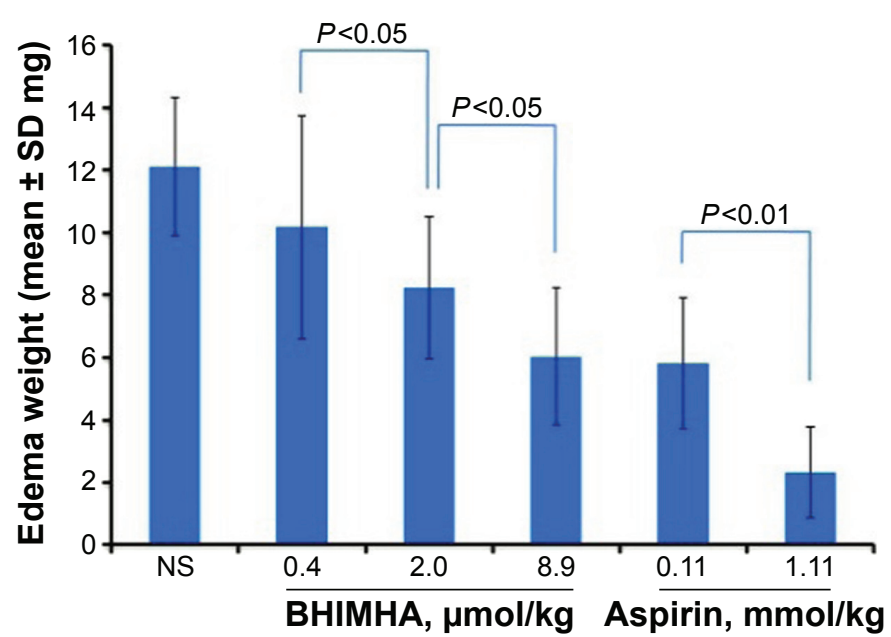

B

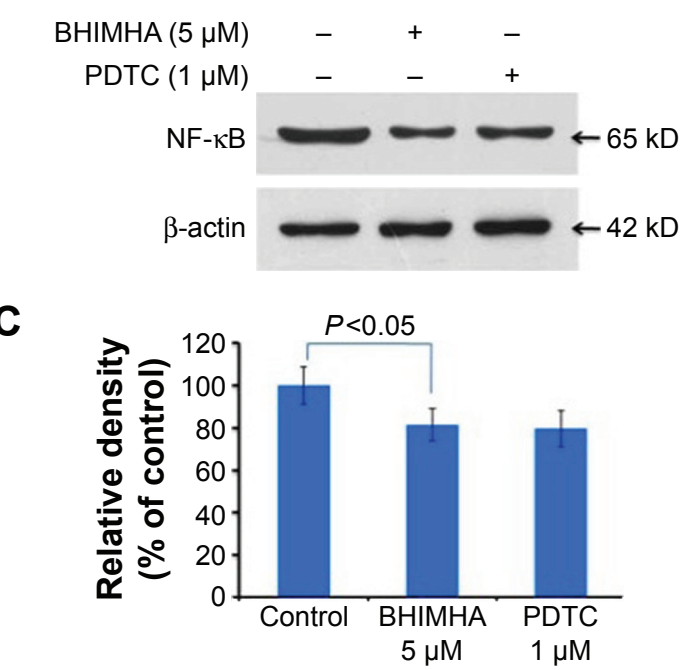

Figure 8 (A) In vivo activity of BHIMHA inhibiting xylene-induced ear edema of ICR mice, $n=10$; (B, C) effect of BHIMHA on the expression of NF- $\mathrm{B} B$ from $A 549$ cells, $n=3$. Abbreviations: NS, normal saline; NF- $\mathrm{BB}$, nuclear factor- $\mathrm{KB}$; SD, standard deviation; BHIMHA, 5-(bis(3-(2-hydroxyethyl)-IH-indol-2-yl)methyl)-2-hydroxybenzoic acid; PDTC, ammonium pyrrolidinedithiocarbamate; Aspirin, acetylsalicylic acid.

migration and invasion of A549 cells. In vivo, BHIMHA dose dependently inhibits the metastasis of LLC toward lung, dose dependently inhibits the tumor growth of C57BL/6 mice and S180 mice, and dose dependently inhibits xylene-induced ear edema of ICR mice. These activities support the rationality of BHIMHA design. In vitro, BHIMHA downregulates the expressions of $\mathrm{PKC} \alpha$ and NF- $\mathrm{KB}$ from the treated A549 cells and provides a clue to disclose the action mechanism.

\section{Acknowledgments}

This work was supported by Beijing Municipal Science and Technology Commission (Z141100002114049), PXM 2013014226000002, TJSHG (201310025008), IHLB (KZ201210025021), Beijing Nova Program (grant number XX2013039), National Natural Science Foundation (81172930, 81273379, 81373264, 81373265, and 81270046) and 863 program (2015AA020902), Beijing Natural Science Foundation (7132032).

\section{Disclosure}

The authors report no conflicts of interest in this work.

\section{References}

1. Temel JS, Greer JA, Muzikansky A, et al. Early palliative care for patients with metastatic non-small-cell lung cancer. N Engl J Med. 2010; 363(8):733-742.

2. Pao W, Chmielecki J. Rational, biologically based treatment of EGFRmutant non-small-cell lung cancer. Nat Rev Cancer. 2010;10(11): 760-774.

3. McCulloch M, See C, Shu X, et al. Astragalus-based Chinese herbs and platinum-based chemotherapy for advanced non-small-cell lung cancer: meta-analysis of randomized trials. J Clin Oncol. 2006;24(3): 419-430.
4. Stewart BW, Wild CP. World Cancer Report 2014. Geneva, Switzerland: World Health Organization; 2014.

5. Nguyen DX, Bos PD, Massagué J. Metastasis: from dissemination to organ-specific colonization. Nat Rev Mol Cell Biol. 2009;9(4): 274-284.

6. Rosse C, Linch M, Kermorgant S, et al. PKC and the control of localized signal dynamics. Nat Rev Mol Cell Biol. 2010;11(2):103-112.

7. Kang JH, Asai D, Toita R, et al. Plasma protein kinase C (PKC) $\alpha$ as a biomarker for the diagnosis of cancers. Carcinogenesis. 2009;30(11): 1927-1931.

8. Garg R, Benedetti LG, Abera MB, et al. Protein kinase C and cancer: what we know and what we do not. Oncogene. 2014;33(45): $5225-5237$.

9. Shi MD, Shih YW, Lee YS, et al. Suppression of 12-O-tetradecanoylphorbol-13-acetate-induced MCF-7 breast adenocarcinoma cells invasion/migration by $\alpha$-tomatine through activating $\mathrm{PKC} \alpha / \mathrm{ERK} /$

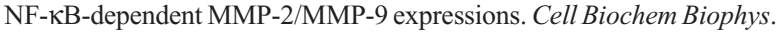
2013;66(1):161-174.

10. Lin CW, Shen SC, Chien CC, et al. 2-O-tetradecanoylphorbol-13acetate-induced invasion/migration of glioblastoma cells through activating PKC $\alpha / \mathrm{ERK} / \mathrm{NF}-\mathrm{\kappa B}-\mathrm{dependent} \mathrm{MMP-9}$ expression. J Cell Physiol. 2010;225(2):472-481.

11. Wu TT, Hsieh YH, Hsieh YS, et al. Reduction of PKC $\alpha$ decreases cell proliferation, migration, and invasion of human malignant hepatocellular carcinoma. J Cell Biochem. 2008;103(1):9-20.

12. Mahanivong $\mathrm{C}$, Chen HM, Yee SW, et al. Protein kinase C $\alpha$-CARMA3 signaling axis links Ras to NF- $\mathrm{\kappa B}$ for lysophosphatidic acid-induced urokinase plasminogen activator expression in ovarian cancer cells. Oncogene. 2008;27(9):1273-1280.

13. Wang Y, Yang H, Liu H, et al. Effect of staurosporine on the mobility and invasiveness of lung adenocarcinoma A549 cells: an in vitro study. BMC Cancer. 2009;9(1):174.

14. Cheng X, Gu J, Zhang M, et al. Astragaloside IV inhibits migration and invasion in human lung cancer A549 cells via regulating PKC $\alpha-$ ERK1/2-NF-KB pathway. Int Immunopharmacol. 2014;23(1):304-313.

15. Tong J. Effect of 7-hydroxystaurosporine on glioblastoma cell invasion and migration. Acta Pharmacol Sin. 2005;26(4):492-499.

16. Tsai CH, Hsieh YS, Yang SF, et al. Matrix metalloproteinase 2 and matrix metalloproteinase 9 expression in human oral squamous cell carcinoma and the effect of protein kinase C inhibitors: preliminary observations. Oral Surg Oral Med Oral Pathol Oral Radiol Endod. 2003;95(6):710-716. 
17. Wu Y, Zhou BP. Inflammation: a driving force speeds cancer metastasis. Cell Cycle. 2009;8(20):3267-3273.

18. Mantovani A, Allavena P, Sica A, et al. Cancer-related inflammation. Nature. 2008;454(7203):436-444.

19. Karin M. Nuclear factor- $\mathrm{\kappa B}$ in cancer development and progression. Nature. 2006;441(7092):431-436.

20. Wang Y, Yang H, Liu H, et al. Effect of staurosporine on the mobility and invasiveness of lung adenocarcinoma A549 cells: an in vitro study. BMC Cancer. 2009;9(1):174.

21. Li S, Wang Y, Zhao M, et al. BPIC: a novel anti-tumor lead capable of inhibiting inflammation and scavenging free radicals. Bioorg Med Chem Lett. 2015;25(5):1146-1150.

22. Wang W, Zhao M, Wang Y, et al. \{2-[1-(3-Methoxycarbonylmethyl-1Hindol-2-yl)-1-methyl-ethyl]-1H-indol-3-yl\}-acetic acid methyl ester (MIAM): its anti-cancer efficacy and intercalation mechanism identified via multi-model systems. Mol Biosyst. 2011;7(3):766-772.

23. Li Y, Wang W, Xu X, Sun S, Qu XJ. \{2-[1-(3-Methoxycarbonylmethyl1H-indol-2-yl)-1-methyl-ethyl]-1H-indol-3-yl\}-acetic acid methyl ester (MIAM) inhibited human hepatocellular carcinoma growth through upregulation of Sirtuin-3 (SIRT3). Biomed Pharmacother. 2015;69: $125-132$.
24. Wang F, Li S, Wang Y, et al. Enantiomeric diketopiperazines: getting insight of the impact of the configuration to the conformation, nanoimage, u-PA inhibition and anti-metastatic activity. MedChem Comm. 2015; 6:956-962.

25. Panigrahy D, Edin ML, Lee CR, et al. Epoxyeicosanoids stimulate multiorgan metastasis and tumor dormancy escape in mice. J Clin Invest. 2012;122(1):178.

26. Wang Y, Li P, Wang S, et al. Anticancer peptidylarginine deiminase (PAD) inhibitors regulate the autophagy flux and the mammalian target of rapamycin complex 1 activity. J Biol Chem. 2012;287(31): 25941-25953.

27. Wagner J, von Matt P, Sedrani R, et al. Discovery of 3-(1H-Indol3-yl)-4-[2-(4-methylpiperazin-1-yl)quinazolin-4-yl]pyrrole-2,5dione (AEB071), a potent and selective inhibitor of protein kinase $\mathrm{C}$ isotypes[J]. J Med Chem. 2009;52(20):6193-6196.

\section{Publish your work in this journal}

Drug Design, Development and Therapy is an international, peerreviewed open-access journal that spans the spectrum of drug design and development through to clinical applications. Clinical outcomes, patient safety, and programs for the development and effective, safe, and sustained use of medicines are a feature of the journal, which has also been accepted for indexing on PubMed Central. The manuscript management system is completely online and includes a very quick and fair peer-review system, which is all easy to use. Visit http://www.dovepress.com/testimonials.php to read real quotes from published authors.

Submit your manuscript here: http://www.dovepress.com/drug-design-development-and-therapy-journal 